\title{
Investigation of Maturation Failure in Revascularization
}

\author{
Gokhan Saygilii ${ }^{1 *}$ and Ece Avci ${ }^{2}$ \\ ${ }^{1}$ DDS PhD, Private Clinic, Afyon, Turkey \\ ${ }^{2} D D S$, Private Clinic, Izmir, Turkey
}

*Corresponding author: Gokhan Saygili, Ballipinar Dental Clinic, Afyon, Turkey.

Received Date: October 15, 2018

Published Date: October 29, 2018

\section{Abstract}

One of the major aims of revascularization therapy is to complete the physiological mechanism of the tooth. It is very difficult to regenerate the pulp which consists of a specialized tissue and maintain its durability especially in a previously infected area. The purpose of this review is to investigate the reasons for the uncompleted maturation stage in the regenerating pulp tissue.

Keywords: Revascularization; Immature teeth; SCAP; MTA; Maturation failure

\section{Introduction}

The root canal treatment is performed after pulp necrosis or a certain inflammatory phase in the contemporary endodontic treatment of mature teeth because there is no collateral circulation in the root canal space [1]. Researchers and clinicians try to create a pulp-like tissue in root canals of the immature teeth [2-6]. Building a sound, physiologic pulp that is capable of generating hard tissue is very challenging due to the loss of vital tissue, bacteria penetrated into dentin tubules and the changes of the tissue around the tooth $[7,8]$. Case reports and studies have shown [9-11] that researchers are able to disinfect root canal space, stimulate living tissue formation and provide adequate coronal sealing. The most common method to measure the success of the treatment is radiography [12]. Hard tissue formation is indicative of the health status of the immature root canal and this can be detected via radiographs [13]. However, hard tissue accumulation in the root canal space may not be observed in all cases [6]. In this review, it has been investigated why there is not always hard tissue formation in the root canal cavity such as in the alveolar bone in revascularization therapies.

MTA (Mineral Trioxide Aggregate) is often essential in revascularization treatment protocols [2,5]. MTA provides a decent coronal sealing [14]. It is hydrophilic [14], biocompatible [15] and even bio stimulating [16]. MTA forms an alkaline medium in the area that aids cell migration and proliferation during its setting $[7,17]$. It accelerates osteoblastic / odontoblastic differentiation of stem cells and generates a higher quality dentin than calcium hydroxide [4,15]. It is known that there is a positive correlation between odontoblastic cells and MTA [15]. MTA treated teeth observed $[2,8,11]$ hard tissue accumulation in the root canal and an increase in apical length especially in young patients.

More than 500 varieties of microorganisms can be found in the infected root canal space [18]. Enterococcus faecalis is one of the most resistant bacteria found in root canals [19]. The success of antimicrobial agents is tested on E. faecalis [19]. Agood antimicrobial agent or medicament should also not restrict the revascularization process because SCAP (Stem Cell Apical Papilla) and mesenchymal stem cells in the periapical area may have an active role during revascularization $[2,20]$. However, various antimicrobial agents and medicaments are toxic on these cells and tissues [21]. Antibiotic pastes have a negative effect on stem cells, even though they are diluted several times [21,22]. Sodium hypochlorite is highly toxic in periapical tissue and may cause unwanted clinical problems [23]. In fact, regenerative endodontics needs a medication that has powerful antimicrobial properties as well as an MTA-like effect on cells. Nevertheless, side effects can be minimized by being careful not to overflow medication and solutions in the periapical area.

In the treatment of revascularization, many researchers intend to induce new tissue formation by irritating the periapical area to cause bleeding; which is considered a successful technique by some $[5,8]$. In addition, stem cells brought by bleeding into the canal space can use the benefit of the alkaline environment and excrete 
special factors thus initiate the regeneration process [5]. The idea of bringing the stem cells in the apical area into the canal cavity may be reasonable. However, inducing bleeding technique was not successful in all of the studies [24]. According to some researchers $[10,25,26]$, this procedure is not mandatory, and revascularization can also be achieved without bleeding.

The healing rate of endodontic lesions is inversely proportional to age [27]. The stem cells in young patients are much more capable of releasing extrinsic and intrinsic factors [28]. This cannot be the reason of the lack of maturation in the roots of elderly patients, as various case reports have stated $[3,29]$ that there is no calcification within the root canal in the long term after revascularization.

Neural crest originated dental pulpal stem cells, dental follicle stem cells, periodontal stem cells and SCAP can be turned into odontoblasts [30]. However, the dental pulp stem cells are not naturally present in the non-vital pulp. As the dental follicle stem cell is found in the dental follicle, it disappears with age. Periodontal stem cells are highly differentiated cells and their migration to the regeneration area is difficult due to location disadvantage. SCAP cells can survive in periapex lifelong and are not far from the apical area [20]. In young patients, these cells have a primary effect in the treatment of revascularization $[2,26]$. There are many studies on the behavior of SCAP cells against signaling pathways and materials [31-33]. The presence of SCAP cells in periapex with granuloma or cyst histopathology is a mystery. Such tissue has severe tissue destruction. Defense cells dominate the region [34]. The SCAP cells may not survive long in periapex where tissue is dealing with microorganism wastes and destruction products [35]. Also, these cells may not play a major role in revascularization process, whether the apical area irritated to bleed or not [35]. This hypothesis explains why maturation is not possible when it comes to revascularization treatment.

Dentine is produced by odontoblasts while osteoblasts form bone tissue $[1,30]$. Although odontoblasts exhibit similar characteristics to osteoblasts, they have different embryonic backgrounds [30]. The quality and markers of the hard tissue produced by them differs [30]. Stem cells need a proper microenvironment and niche for being transformed into programmable cells [36]. The transformation of the stem cells begins if the stem cell receptors feel certain about the signals and that they are in the appropriate tissue [37]. Mesenchymal stem cells can be found both in the pulp and in the alveolar bone [38]. This stem cell can differentiate into many cell types according to the medium [39]. The mesenchymal stem cell has the ability to transform into osteodentin-like stem cell in the root canal [40]. However, all conditions must be appropriate for the osteogenic cell conversion of mesenchymal stem cells [40]. The intradentin has to be treated physically and chemically to be revascularized. The medicaments and solutions being used may be free of microorganisms, but the root canals may contain cell residues, debridement or chemical agents. the mesenchymal stem cell may prefer to form a connective tissue cell instead of the osteogenic pathway in such an environment $[1,41]$. A tooth has been examined histologically 5 years after revascularization treatment by Orduna JFG et al. [42]. They stated that there was no hard tissue in the pulp tissue and a vascularized connective tissue was present.

Many studies are still in progress to manage complete maturation of the immature necrotic teeth. There is sufficient number of studies on revascularization therapies especially in young patients. However; there is no detailed literature about revascularization treatments and maturation rates in adult patients. The main important reason for this problem is the low capacity of regeneration in adult patients, for sure. In order to enhance the regeneration ability of adult patients, preclinical and clinical applications of stem cell therapies need to be developed.

\section{References}

1. Ingle JI, Beveridge EE, Glick DH, Weichman JA, Abou-Rass MJE (1994) Modern endodontic therapy. 2:1-57.

2. Wigler R, Kaufman AY, Lin S, Steinbock N, Hazan Molina H, et al. (2013) Revascularization: a treatment for permanent teeth with necrotic pulp and incomplete root development. J Endod 39(3): 319-326.

3. Jadhav GR, Shah N, Logani A (2014) Platelet-rich plasma supplemented revascularization of an immature tooth associated with a periapical lesion in a 40-year-old man. Case Rep Dent 2014: 479584.

4. Leye Benoist F, Gaye Nzdiaye F, Kane AW, Benoist HM, Farge P (2012) Evaluation of mineral trioxide aggregate (MTA) versus calcium hydroxide cement $\left(\right.$ Dycal $\left.{ }^{\circledR}\right)$ in the formation of a dentine bridge: a randomised controlled trial. Int Dent J 62(1): 33-39.

5. Nosrat A, Seifi A, Asgary S (2011) Regenerative endodontic treatment (revascularization) for necrotic immature permanent molars: a review and report of two cases with a new biomaterial. J Endod 37(4): 562-567.

6. Wang Y, Zhu X, Zhang C (2015) Pulp revascularization on permanent teeth with open apices in a middle-aged patient. J Endod 41(9): 15711575.

7. Sen B, Piskin B, Demirci T (1995) Observation of bacteria and fungi in infected root canals and dentinal tubules by SEM. Endod Dent Traumatol 11(1): 6-9.

8. Chen MY, Chen KL, Chen CA, Tayebaty F, Rosenberg P, et al. (2012) Responses of immature permanent teeth with infected necrotic pulp tissue and apical periodontitis/abscess to revascularization procedures. Int Endod J 45(3): 294-305.

9. Thibodeau B, Trope M (2007) Pulp revascularization of a necrotic infected immature permanent tooth: case report and review of the literature. Pediatr Dent 29(1): 47-50.

10. Torabinejad M, Turman M (2011) Revitalization of tooth with necrotic pulp and open apex by using platelet-rich plasma: a case report. J Endod 37(2): 265-268.

11. Banchs F, Trope M (2004) Revascularization of immature permanent teeth with apical periodontitis: new treatment protocol? J Endod 30(4): 196-200.

12. Vire DE (1991) Failure of endodontically treated teeth: classification and evaluation. J Endod 17(7): 338-342.

13. Yates JA (1988) Barrier formation time in non-vital teeth with open apices. Int Endod J 21(5): 313-319.

14. Al Kahtani A, Shostad S, Schifferle R, Bhambhani S (2005) In-vitro evaluation of microleakage of an orthograde apical plug of mineral trioxide aggregate in permanent teeth with simulated immature apices. J Endod 31(2): 117-119.

15. Mitchell P, Ford TP, Torabinejad M, Mc Donald F (1999) Osteoblast biocompatibility of mineral trioxide aggregate. Biomaterials 20(2): 167173.

16. Daltoe MO, Paula Silva FWG, Faccioli LH, Gaton Hernandez PM, De Rossi A, et al. (2016) Expression of mineralization markers during pulp 
response to biodentine and mineral trioxide aggregate. J Endod 42(4): 596-603.

17. Yasuda Y, Izumikawa M, Okamoto K, Tsukuba T, Saito T (2008) Dentin phosphophoryn promotes cellular migration of human dental pulp cells. J Endod 34(5): 575-578.

18. Jung IY, Choi Bk, Kum KY, Roh BD, Lee SJ (2000) Molecular epidemiology and association of putative pathogens in root canal infection. J Endod. 26(10): 599-604.

19. Stuart CH, Schwartz SA, Beeson TJ, Owatz CB (2006) Enterococcus faecalis: its role in root canal treatment failure and current concepts in retreatment. J Endod. 32(2): 93-98.

20. Sonoyama W, Liu Y, Yamaza T, Tuan RS, Wang S, et al. (2008) Characterization of the apical papilla and its residing stem cells from human immature permanent teeth: a pilot study. J Endod 34(2): 166171.

21. Labban N, Yassen GH, Windsor LJ, Platt JA (2014) The direct cytotoxic effects of medicaments used in endodontic regeneration on human dental pulp cells. J Endod 30(6): 429-434.

22. Chuensombat S, Khemaleelakul S, Chattipakorn S, Srisuwan T (2013) Cytotoxic effects and antibacterial efficacy of a 3-antibiotic combination: an in vitro study. J Endod 39(6): 813-819.

23. Moorer W, Wesselink PJ (1982) Factors promoting the tissue dissolving capability of sodium hypochlorite. Int Endod J 15(4): 187-196.

24. Lin LM, Shimizu E, Gibbs JL, Loghin S, Ricucci D (2014) Histologic and histobacteriologic observations of failed revascularization/revitalization therapy: a case report. J Endod 40(2): 291-295.

25. Nosrat A, Homayounfar N, Oloomi K (2012) Drawbacks and unfavorable outcomes of regenerative endodontic treatments of necrotic immature teeth: a literature review and report of a case. J Endod 38(10): 14281434

26. Cehreli ZC, Isbitiren B, Sara S, Erbas G (2011) Regenerative endodontic treatment (revascularization) of immature necrotic molars medicated with calcium hydroxide: a case series. J Endod 37(9): 1327-1330.

27. Eriksen H, Bjertness E (1991) Prevalence of apical periodontitis and results of endodontic treatment in middle-aged adults in Norway. Endod Dent Traumatol 7(1): 1-4.

28. Kumar V, Abbas AK, Fausto N, Aster JC (2005) Robbins and Cotran pathologic basis of disease ( $7^{\text {th }}$ edn). In: Philadelphia: Elsevier Saunders, USA.

29. Shah N, Logani A (2012) Seal Bio: A novel, non-obturation endodontic treatment based on concept of regeneration. J Conserv Dent 15(4): 328332.
30. Achilleos A, Trainor PA (2012) Neural crest stem cells: discovery, properties and potential for therapy. Cell Res 22(2): 288.

31. Ruparel NB, Teixeira FB, Ferraz CC, Diogenes A (2012) Direct effect of intracanal medicaments on survival of stem cells of the apical papilla. J Endod 38(10): 1372-1375

32. Shrestha S, Torneck CD, Kishen A (2016) Dentin conditioning with bioactive molecule releasing nanoparticle system enhances adherence viability, and differentiation of stem cells from apical papilla. J Endod 42(5): 717-723.

33. Bellamy C, Shrestha S, Torneck C, Kishen A (2016) Effects of a bioactive scaffold containing a sustained transforming growth factor- $\beta 1$-releasing nanoparticle system on the migration and differentiation of stem cells from the apical papilla. J Endod 42(9): 1385-1392.

34. Wayman BE, Murata SM, Almeida RJ, Fowler (1992) A bacteriological and histological evaluation of 58 periapical lesions. J Endod 18(4): 152 155.

35. Vijayaraghavan R, Mathian VM, Sundaram AM, Karunakaran R, Vinodh S (2012) Triple antibiotic paste in root canal therapy. J Pharm Bioallied Sci 4(Suppl 2): S230-S233.

36. Fuchs E, Tumbar T, Guasch G (2004) Socializing with the neighbors: stem cells and their niche. Cell 116(6): 769-778.

37. Schuldiner M, Yanuka O, Itskovitz-Eldor J, Melton DA, Benvenisty N (2000) Effects of eight growth factors on the differentiation of cells derived from human embryonic stem cells. Proc Natl Acad Sci U S A 97(21): 11307-11312.

38. Shi S, Bartold P, Miura M, Seo B, Robey P, et al. (2005) The efficacy of mesenchymal stem cells to regenerate and repair dental structures. Orthod Craniofac Res 8(3): 191-199.

39. Pittenger MF, Mackay AM, Beck SC, Jaiswal RK, Douglas R, et al. (1999) Multilineage potential of adult human mesenchymal stem cells. Science 284(5411): 143-147.

40. Narayanan K, Srinivas R, Ramachandran A, Hao J, Quinn B, et al. (2001) Differentiation of embryonic mesenchymal cells to odontoblast-like cells by overexpression of dentin matrix protein 1. Proc Natl Acad Sci U S A 98(8): 4516-4521.

41. Grigoratos D, Knowles J, Ng YL, Gulabivala K (2001) Effect of exposing dentine to sodium hypochlorite and calcium hydroxide on its flexural strength and elastic modulus. Int Endod J 34(2): 113-119.

42. Orduna JFG, Caviedes-Bucheli J, Cespedes MCM, Jimeno EB, Biedma BM et al. (2017) Use of platelet-rich plasma in endodontic procedures in adults: regeneration or repair? A report of 3 cases with 5 years of followup. J Endod 43(8): 1294-1301. 